\title{
Serum zinc and manganese levels in subjects with type 2 diabetes mellitus
}

\author{
Hossneara Eva1, Qazi Shamima Akhter², Md. Khairul Alam
}

\begin{abstract}
Background: Serum level of several trace elements such as zinc ( $\mathrm{Zn})$ and manganese (Mn) levels are altered in type $2 \mathrm{DM}$ and its deficiencies are associated with the development of microvascular and macrovascular complications. Objective: To assess the serum zinc ( $\mathrm{Zn}$ ) and manganese (Mn) levels in subjects with type 2 diabetes mellitus. Methods: This cross sectional study was conducted in the Department of Physiology, Dhaka Medical College, Dhaka from July 2014 to June 2015. Fifty type 2 diabetic subjects with age ranging from 40 to 55 years of both sexes were study group and 50 age, sex and BMI matched healthy subjects were control group. Patients were selected from Bangladesh Institute of Research for Diabetic Endocrine and Metabolic Disorders (BIRDEM) General Hospital, Dhaka. Serum $\mathrm{Zn}$ and Mn levels were estimated by flame atomic absorption spectrophotometry. For statistical analysis, unpaired Student's 't' test and chi square test was performed. Results: In this study, mean serum zinc and manganese levels were significantly $(\mathrm{P}<0.001)$ lower in the study group than that of control group. In addition, hypozincemia in 36\% and hypomanganesemia in 18\% of diabetic patients were observed and which was significantly $(\mathrm{p}<0.001)$ higher than those of control. Conclusion: From this study, it may be concluded that serum zinc and manganese deficiencies may develop as diabetes related complications.
\end{abstract}

Key words: Serum zinc, serum manganese, type 2 diabetes mellitus.

J Bangladesh Soc Physiol. 2016, December; 11(2): 50-53

For Authors Affiliation, see end of text.

http://www.banglajol.info/index.php/JBSP

\section{Introduction}

D iabetes mellitus (DM) is a metabolic disorder of carbohydrate, lipid and protein metabolism. It is characterized by hyperglycemia due to defects of insulin secretion or of insulin action, or both ${ }^{1}$. Diagnostic criteria of diabetes mellitus are fasting blood glucose level of $\geq 7.0 \mathrm{mmol} / 1$, after 2 hour value of $\geq 11.1 \mathrm{mmol} / 1$ in $75 \mathrm{~g}$ oral glucose tolerance test and $\mathrm{HbA}_{\mathrm{IC}}$ of $\geq 6.5 \%{ }^{2}$.

Diabetes mellitus is a major global health problem. Prevalence of diabetes in Bangladesh was 5.1 million in the year $2013^{3}$. In developing

Received 16th June 2016; Accepted 11 Sept. 2016 counteries, most of people suffering from diabetes are aged between 40 to 60 years and this number is increasing day by day ${ }^{4}$. Chronic hyperglycemia produces macrovascular complications like coronary artery disease, peripheral arterial disease, stroke and microvascular complications like retinopathy, nephropathy, neuropathy ${ }^{5}$.

Zinc ( $\mathrm{Zn})$ is required for synthesis, storage and secretion of insulin ${ }^{6}$. Diabetes and poor glycaemic control alters the metabolism of $\mathrm{Zn}$ by increasing urinary excretion and lowering serum $\mathrm{Zn}$ levels ${ }^{7}$. In type 2 diabetic patients, insufficient dietary $\mathrm{Zn}$ intake increases the risk 
of coronary heart disease, hypertension, retinopathy, thrombosis 8,9 .

Manganese (Mn) acts as a cofactor with antioxidant enzyme like superoxide dismutase which helps to remove free radicals ${ }^{10}$. Diabetes causes increase urinary excretion and lower serum level of $\mathrm{Mn}^{11}$. Manganese deficiency increases oxidative stress in diabetic patients causing development of diabetic complications ${ }^{12}$. Diabetics with lower serum level of Mn were less protected from oxidation of low density lipoprotein (LDL) cholesterol. This oxidation of LDL contributes to the development of intra-arterial plaque that can lead to heart attack and stroke ${ }^{13}$.

It is obvious that lower serum zinc and manganese levels increase the risk of diabetic complications in type 2 diabetes mellitus. This study aimed to create further awareness among the physicians and type 2 diabetic patients in Bangladesh regarding the diabetic complications that may occur due to zinc and manganese deficiencies.

\section{Methods}

This cross sectional study was done in the Department of Physiology, Dhaka Medical College, Dhaka from July 2014 to June 2015. Protocol of this study was approved by Ethical review committee of Dhaka Medical College and Diabetic Association of Bangladesh. For this study 50 subjects (28 male and 22 female), age (40-55 years), type 2 diabetic patients with fasting blood glucose FBG level $<7.0 \mathrm{mmol} / 1$ and $\mathrm{HbA}_{1 \mathrm{C}} \mathrm{e}$ " $6.5 \%$ were selected from out patient department of BIRDEM General Hospital, Dhaka and 50 age, BMI matched healthy subjects (26 male and 24 female) were control. After selection of the subjects, the nature, purpose and benefit of the study were explained to each subject in details and informed written consent was taken. Before taking blood, detailed family and medical history were taken. Anthropometric measurement of the subjects was done and blood pressure was measured. All the information was recorded in a data schedule. With aseptic precaution, $20 \mathrm{ml}$ of venous blood was collected from ante-cubital vein by a disposable plastic syringe from each subject for estimation of biochemical tests. $\mathrm{HbA}_{1 \mathrm{c}}$, fasting blood glucose (FBF) levels were estimated in the laboratory of the Department of Biochemistry, BIRDEM General Hospital, Dhaka. Serum zinc and manganese levels were estimated in the laboratory of the Department of Chemistry, Atomic Energy Centre, Dhaka. Statistical analysis were done by unpaired Student's 't' test \& chi square test. $\mathrm{P}$ value $<0.05$ was accepted as level of significance. Statistical analyses were performed by using a computer based statistical program SPSS Version 20.

\section{Results}

General characteristics are presented in table I. In this study mean serum zinc and manganese levels were significantly $(p<0.001)$ lower in patients with type 2 diabetes mellitus (Table II). In addition, hypozincemia was found in $36 \%$ of diabetic patients \& $10 \%$ of nondiabetic subjects. Again hypomanganeseemia was found in 18\% diabetic \& $4 \%$ of nondiabetics. The differences of hypozincemia \& hypomanganesemia between diabetic \& nondiabetic subjects were highly significant $(\mathrm{p}<0.001)$ (Table III).

Table I: General characteristics of the subjects in both groups $(n=100)$

\begin{tabular}{lcc}
\hline Parameters & $\begin{array}{c}\text { Control } \\
(\mathrm{n}=50)\end{array}$ & $\begin{array}{c}\text { Diabetic patients } \\
(\mathrm{n}=50)\end{array}$ \\
\hline Age (years) & $47.58 \pm 3.59$ & $48.00 \pm 3.49$ \\
Sex & & \\
Male & $26(52.0)$ & $28(56.0)$ \\
Female & $24(48.0)$ & $22(44.0)$ \\
Height $(\mathrm{cm})$ & $59.54 \pm 5.20$ & $158.32 \pm 8.17$ \\
Weight $(\mathrm{kg})$ & $64.62 \pm 5.51$ & $64.54 \pm 8.21$ \\
Body mass index & \\
(kg/m $\left.{ }^{2}\right)$ & $25.44 \pm 2.06$ & $25.80 \pm 3.06$ \\
Systolic blood pressure & \\
(mmHg) & $121.70 \pm 5.31$ & $123.40 \pm 7.45$ \\
Diastolic blood pressure & \\
(mmHg) & $76.30 \pm 5.70$ & $79.70 \pm 5.19$ \\
\hline
\end{tabular}

Sex distribution has been shown in number and percentage. All other results are expressed as mean \pm SD. Unpaired Student's ' $t$ ' test was performed to compare between groups. $n=$ Number of subjects. 
Table II: Serum Zinc and Manganese levels of the subjects in both groups $(\mathrm{n}=100)$

\begin{tabular}{lcc}
\hline Parameters & $\begin{array}{c}\text { Control } \\
(\mathrm{n}=50)\end{array}$ & $\begin{array}{c}\text { Diabetic patients } \\
(\mathrm{n}=50)\end{array}$ \\
\hline $\begin{array}{l}\text { Serum zinc } \\
(\mu \mathrm{g} / \mathrm{dl})\end{array}$ & $89.91 \pm 17.48$ & $71.77 \pm 19.95^{* * *}$ \\
Serum manganese & $12.95 \pm 2.76$ & $10.45 \pm 2.77^{* * * *}$ \\
$(\mathrm{ng} / \mathrm{ml})$ & $(8.0718 .89)$ & $(6.6316 .40)$ \\
\hline
\end{tabular}

Data are expressed as mean \pm SD. Unpaired Student's ' $t$ ' test was performed to compare between groups. $* * * \mathrm{p}<0.001$.

Table III: Frequency distribution of hypozincemia and hypomanganasemia in both groups $(\mathrm{n}=100)$

\begin{tabular}{lcc}
\hline Parameters & $\begin{array}{c}\text { Control } \\
(\mathrm{n}=50) \\
\text { no. }(\%)\end{array}$ & $\begin{array}{c}\text { Diabetic patients } \\
(\mathrm{n}=50) \\
\text { no. }(\%)\end{array}$ \\
\hline Hypozincemia & $5(10)$ & $18(36) * * *$ \\
Hypomanganesemia & $2(4)$ & $9(18) * * *$ \\
\hline
\end{tabular}

Data was analyzed by Chi square test. $* * * \mathrm{p}<0.001$. Cut point for $\mathrm{Zn}<72 \mu \mathrm{g} / \mathrm{dl} \& \mathrm{Mn}<4.7 \mathrm{ng} / \mathrm{ml}^{26,27}$.

\section{Discussion}

In the present study, mean serum zinc level was significantly lower in type 2 diabetic patients than that of adult healthy subjects. This finding is in agreement with others ${ }^{1,12,14-16}$ But some investigators found higher $\mathrm{Zn}$ levels in type 2 diabetic subjects ${ }^{17}$.

Again, in the present study, serum manganese level was found lower in type 2 diabetic patients than that of healthy adult subjects. Similar finding was also made by other research workers 13,18 , ${ }^{19}$. On the contrary, some researchers observed no significant difference in serum manganese level between type 2 diabetic subjects and adult healthy subjects 20,21 .

In this study, significant numbers of diabetic patients are found with hypozincemia and hypomanganeseemia. From this study the pathogenesis of low zinc and manganese level in diabetic is not clear. But literature review suggested that prolonged hyperglycemia in uncontrolled diabetes causes polyuria due to osmotic diuresis. This cause increased excretion

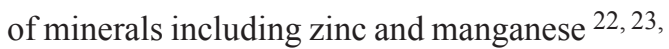
24,25 . As a result without adequate dietary replacement of these two minerals, deficiency of $\mathrm{Zn}$ and Mn may develop in diabetics.

In the present study the poor zinc and manganese levels in the diabetic subjects may be related to the increased urinary excretion and without dietary replacement of these two minerals.

\section{Conclusion}

From the results of the study, it may be concluded that zinc and manganese deficiencies may develop as diabetes related complications in type 2 diabetic patients.

\section{Acknowledgement}

The authors acknowledge Department of Biochemistry, BIRDEM General Hospital, Dhaka and Department of Chemistry, Atomic Energy Centre, Dhaka for their kind cooperation to carry out my laboratory investigations.

\section{Conflict of Interest None}

\section{Authors affiliations}

1. *Hossneara Eva. Assistant Professor, Department of Physiology, Brahmanbaria Medical College, Brahmanbaria. Email: hossnearaeva@gmail.com

2. Quzi Shamima Akhter. Professor and Head, Department of Physiology, Dhaka Medical College, Dhaka.

3. Md. Khairul Alam. Professor and Head, Department of Physiology, Army Medical College, Comilla.

*For correspondance

\section{References}

1. Preveeena S, Pasula S, Sameera K. Trace elements in diabetes mellitus. J Clin Diagn Res. 2013; 7(9): 1863-5.

2. Seino Y, Nanjo K, Tajima N, Kadowaki T, Kashiwagi A, Araki E, Ito C, Inagaki N, Iwamoto Y, Kasuga M, Hanafusa T, Haneda M, Ueki K. Report of the committee on the classification and diagnostic criteria of diabetes mellitus. J Diabetes Invest. 2010; 1 (5): 212-28.

3. Guariguata L, Whiting DR, Hambleton I, Beagley J, Linnenkamp U, Shaw JE.Global estimates of diabetes prevalence for 2013 and projections for 2035. Diabetes Res Clin Pract. 2014; 103 (2014): 137-49. 
4. Shaw JE, Sicree RA, Zimmet PZ. Global estimates of the prevalence of diabetes for 2010 and 2030.Diabetes Res Clin Pract. 2010; 87 (2010): 4-14.

5. Fowler MJ. Microvascular and macrovascular complications of diabetes. Clin Diabetes.2008; 26(2): $77-82$.

6. Yahya H,Yahya KM, Saqib A. Minerals and type 2 diabetes mellitus-level of zinc, magnesium and chromium in diabetic and non diabetic population. JUMDC. 2011; 2 (1): 34-8.

7. Puri M, Gujral U, Nayyar SB. Comparative study of serum zinc, magnesium and copper levels among patients of type 2 diabetes mellitus with and without microangiopathic complications. Innovative J Med Health Sci. 2013; 3 (6): 274-8

8. El-Arab AE, Fouly AH, Mahmoud HH. Effect of blood glucose fluctuation on some trace elements and aldosterone hormone among type 2 diabetic patients with metabolic syndrome. Arab J Nucl Sci Appl. 2014; 47 (2): 201-16.

9. Abdalla BE, Diab AA, Zaki HY, Ali KE. Serum chromium, magnesium and zinc levels in Sudanese type 2 diabetic patients. Gezira J Health Sci. 2011; 17 (1): $1-9$.

10. Hori H, Ohmari O, Shinkai T, Kojima H, Okano C, Suzuki T, Nakamur J. Manganese superoxide dismutase gene polymorphism and schizophrenia: relation to tardive dyskinesia. Neuropsychopharm. 2000; 23(1): 170-7.

11. Akhuemokhan IK, Eregie A, Fasanmade OA. Diabetes prevention and management: the role of trace minerals. Afr J Diabetes Med. 2013; 21 (2): 37-41.

12. Farid SM. The association between serum glucose and serum lead and selected trace elements in type 2 diabetes mellitus patients in Jeddah, Saudi Arabia. Med J Islamic World Acad Sci. 2012; 20 (4): 130-9.

13. Nicoloff G, Mutaftchiev K, Strashimirov D, Petrova C. Serum manganese in children with diabetes mellitus type 1. Diabetologia Croatica. 2004; 33 (2): 47-51.

14. Santa SR, Swati B, Choudhury KM, Santasmita P, Aruna B, Gargi S, Soma G. Status of serum magnesium, zinc \& copper in patients suffering from type 2 diabetes mellitus. J Drug Ther. 2014; 4 (1): 70-2.

15. Lal M, Sudha K, Shetty BV, Rao GM. Influence of modified levels of plasma magnesium, $\mathrm{Cu}, \mathrm{Zn}$ and iron levels on thiols and protein status in diabetes mellitus and diabetic retinopathy. Int J Anal Pharm Biomed Sci. 2013; 2 (1): 67-72
16. Oyedeji SO, Adesina AA, Oke OT, Tijani YO. Evaluation of essential trace metals in female type 2 diabetes mellitus patients in Nigerian population. Afr J Biotechnol. 2014; 13 (18): 1910-4.

17. Emeribe AU, Akpotuzor JO, Etukudo MH. Serum chromium, zinc and testosterone levels in diabetics in University of Calabar Teaching Hospital Calabar Nigeria. J Biol Agric Healthc. 2012; 2 (6): 93-110.

18. Kazi TG, Afridi HI, Kazi N, Jamal MK, Arain MB, Jalbani N, Kandho GA. Copper, chromium, manganese, iron, nickel and zinc levels in biological samples of diabetes mellitus patients. Biol Trace Flem Res. 2008; 122: 1-18.

19. Wali U, Jogana MU, Zarummai AL, Saidu Y. Antioxidant vitamins and trace elements status of diabetics in Sokoto, Nigeria. Niger J Basic Appl Sci. 2011; 19 (1): 130-4.

20. Nourmohammadi I, Shalmani IK, Shaabani M, Gohari L, Nazari H. Zinc, copper, chromium, manganese and magnesium levels in serum and hair of insulindependent diabetics. J Trace Elem Exp Med. 2014; 201(3): 1-5.

21. Nasli-Esfahani E, Faridbod F, Larijani B, Ganjali MR, Norouzi P. Trace element analysis of hair, nail, serum and urine of diabetes mellitus patients by inductively coupled plasma atomic emission spectroscopy. Iranian J Diabetes Lipid Disord.2011; 10: 1-9.

22. Murry RK, Granner DK, Mayes PA, Rodwell VW. Herper's Illustrated Biochemistry, $29^{\text {th }}$ ed. New York: Mcgraw-Hill Medical; 2012.

23. Gardner DG, Dolores. Greenspan's Basic \& Clinical Endocrinology, $9^{\text {th }}$ ed. New York: Mcgraw-Hill Medical; 2011

24. Onah CE, Meludu SC, Dioka CE, Amah U, Okwara $\mathrm{JE}$, Osuji CU. Evaluation of selected trace elements in male type 2 diabetic patients in Nnewi, south eastern Nigeria. IOSR-JDMS. 2013; 1(3): 129-34.

25. Abdullah AM, Salh DM. Determination of serum zinc, manganese, copper and cobalt traces in type two diabetic patients in Sulaimaniyah city using icp technique. Ibn Al-Haitham J Pure Appl Sci. 2012; 25(3): 220-5.

26. Hanlon P, Byers M, Walker BR, et al. Davidson's Principles \& Practice of Medicine, $21^{\text {st }}$ ed. New Delhi: Churchill Livingston, Elsevier; 2010.

27. Jiang $\mathrm{Y}$, Zheng $\mathrm{W}$, Long L, et al. Brain magnetic resonance imaging and manganese concentrations in red blood cells of smelting workers: search for biomarkers of manganese exposure. Neuro Toxicology. 2007; 28: 126-35. 